\title{
THE ART OF WAYANG
}

W

ayang kulit, shadow theatre, which has roots dating back over one thousand years, is one of the most popular, or even the most popular theatre form in Java. The performances, which last the whole night and during which the dalang (puppeteer) animates a few or several dozen puppets, mainly depict stories taken from the Mahabharata or Ramayana. Live gamelan music accompanies the play. The puppets, made of specially prepared and painted leather, are one of the most characteristic elements of wayang, recognized even by those who have never seen any performance. Javanese streets are full of billboards advertising Hollywood superheroes by means of wayang puppets. Heroic warriors from the Mahabharata are everywhere - on hotel signboards, buses, $\mathrm{t}$-shirts and all kinds of souvenirs. Wayang puppets are not only the symbols of shadow theatre - now they are seen as a symbol of Javanese culture and the whole of Indonesia outside its borders. So, they appear in tourist brochures that promote exotic vacations, on the covers of books by Indonesian writers and, most often, in the form of intriguing interior decorations used in TV series and films created in the West.

Although the puppets themselves are becoming more and more popular, their importance and meaning are usually reduced to their aesthetic dimension only. But the puppet used in shadow theatre represents a human being, ${ }^{1)}$ even if it is not an accurate reflection. Their appearance is strictly defined and corresponds to the puppet's character. Puppets differ in size, shape, head position, type of eyes, nose or mouth, ornaments and decorations, the way the feet are arranged, and finally the colours of the polychrome covering them. Each detail has its own meaning and experienced members of the

1) Mrázek (2005: 16). 
audience can recognize the character. So it seems that, at first glance, wayang theatre is extraordinarily traditional and hermetic, inaccessible to viewers who have not sacrificed many sleepless nights learning how to read symbols and the meaning encoded within. In fact, even the most traditional dalangs try to reach the largest possible audience with their performances. They try to keep their message contemporary despite the passage of time and the changing political situation. They want the performances to attract an audience not only through their message, but also with the visual and musical setting. In this way, viewers who know and can read the traditional elements of performances are as satisfied as those who see wayang for the first time. To remain appealing to representatives of "[...] Gen Z, the generation coming of age in today's post-traditional society, referred to in Indonesian internet and media parlance as jaman now (literally, the 'period of now'), [who, according to the cultural commentators] are unable to enjoy wayang as they are attuned to cultural products that are easily accessible, fast-paced, and instantly gratifying." ${ }^{2)}$

The readiness to combine these elements requires a skilful balancing act between tradition and the present, including a search for new forms, new language, new means of expression, new themes, new characters. However, the present-day dalangs show that all experiments and innovations are possible in this theatre, and reforms, although often greeted by the audience with some suspicion and distrust, quickly become part of the performance and, in time, tradition. That is why the definition of wayang is constantly being expanded, and its various elements describing the performance and the importance of its parts, puppets, music or repertoire, gain new shapes and interpretations. It also opens a space for artists who come from outside traditional shadow theatre. They use the critical potential of wayang, treating it as a total art, combining elements of visual arts, theatre, literature, music, religion and philosophy, which defy the divisions and classifications imposed in colonial times. The turning point for many contemporary artists was encountering Wayang Ukur (the name derives from the Indonesian word ukuran meaning "measure") and its creator, Sigit Sukasman. This visual artist, who lived 1936-2009, was one of the precursors of the current exploration redefining the function and character of the puppets used in performances. Wayang Ukur created by him exemplified an innovative and radical thinking about shadow theatre. Each element of the spectacle changed, and everything - not only

2) Cohen (2019: 40). 
the puppets, which he designed and made himself, but also the role of the dalang, use of the screen, dramaturgy of the performance and its language - was subordinated to Sukasman's vision. The wayang created by him, often referred to as a personalized tradition by critics, became an impulse for the creators of visual arts, such as Heri Dono, whose debut coincided with the end of the eighties, and two younger artists - Eko Nugroho and Samuel Indratma, debuting in the turbulent period of the late nineties.

Heri Dono, born in 1960, is now one of the most eminent Indonesian artists. His paintings, sculptures, installations and performances, presented in the most important museums and galleries in the world, are often referred to by critics as glocal art - global and local at the same time. "In Dono's oeuvre, Hindu literature, wayang puppets, animism and Javanese metaphysics meet Fluxus, Indonesian activism and sustainable (but often dodgy) Third World recycling techniques for discarded technologies. Add to this a wicked sense of humour, a palpable taste for pretentiousness and an abuse of power allied to a commitment to social relations and social justice and the scenario is set for a Dono work of art to emerge." ${ }^{\text {3) }}$ Heri Dono draws on the local sources and is inspired by tradition to show analogies between culture and local art and global one. Globalization is for him a pretext for continuous reflection on one's own culture, the understanding of which is necessary for establishing intercultural contacts and easy moving in the modern world (fig. 1).

Wayang Legenda from 1988 is considered to be one of the most important works of Heri Dono, in which the artist refers to the symbols taken from wayang combining them with the legends of Bataks from Sumatra. One year earlier, in 1987, Dono joined Sigit Sukasman's art study, as he recalled years later: "When I saw Sukasman's wayang performances, I realized that there is no division between artistic disciplines, no borders between music, dance, theatre, visual art or applied art, no labels." ${ }^{4)}$ The form of Wayang Ukur performances, the puppets designed by Sukasman and his way of thinking about wayang performances and the role of dalang influenced Heri Dono's further work. Dono, like Sukasman, did not initially act as a dalang. Instead, in the Wayang Legenda performance the puppets were animated by two puppeteers, each by one screen. Both Sukasman and Dono played the role of "over-dalang", who directs, controls and animates the puppeteers taking part in the play. They went beyond tradition, in which the dalang is a kind of

\footnotetext{
3) Zeplin (2007: 8).

4) Welling (2009: 44).
} 
spiritual guide, teacher and master transmitting philosophic and moral values to the audience. The presence of two dalangs and their change of role, the way in which the space in the performance was designed, the use of history taken from the mythology of the Bataks were not only a manifestation of Heri Dono individualism. The innovations introduced by him, disrupting the order and harmony of traditional wayang, are part of a general trend present in contemporary wayang, in which artists transform the order established in colonial times.

The first set of sixty puppets created by Dono especially for Wayang Legenda significantly differed from the wayang canon. The artist showed figures according to their wanda, presenting their personality traits by the shape of the eyes, lips, the size and number of heads (demons, in his interpretation, had three heads), hairstyle, costume and other accessories. But his puppets differed from those known from traditional iconography. The heroes of Dono's paintings often look like flat and stunted wayang silhouettes. Looking at Dono's puppets one gets the impression that the characters designed especially for Wayang Legenda "came out" of his canvases.

The puppets designed by Dono, larger than traditional, due to their new form, resulting from their visuality, not their performative character, forced a change in the way of animation. Traditional wayang puppets are treated by dalangs not only as visual representations of characters appearing in the presented lakons (stories), but also as a tool whose form is as important as functionality. The puppets should be well-balanced and should have profiled handles, so that they can be easily manipulated. The material from which they are made should also be comfortable to use. Meanwhile, the "painted" puppets of Dono couldn't be animated in a "traditional" way. They were made of materials such as bamboo and cardboard, cheap and having completely different properties than the leather which is traditionally used in wayang kulit puppets. On the one hand, the materials that he used were much more like his painting. Yet, on the other hand, they referred to the lifestyle of characters introduced by him, previously absent in wayang. The presence of wong cilik, representatives of the lower classes and the masses, characters absent in a culture dominated by the elite, unsettled the social hierarchy which had existed for centuries in wayang that had been "inscribed into the psyche of most Indonesians as to what is appropriate to represent in certain cultural practices."5) Heri Dono thus questioned the dialectical relationship

5) Rath (2003: 48). 
existing in classical shadow theatre between good and evil, sophistication and vulgarity. The material used to make puppets in a symbolic way emphasized that art is not simply the domain of the elite, but can also be created from what has been rejected by the wealthy and privileged.

Wayang Legenda, playing with Javanese tradition, showed that Heri Dono treats wayang as a form of social, artistic and intercultural communication, which, to be still relevant and appealing for the spectators, should include contemporary content. Heri Dono sought inspiration for Wayang Legenda in the mythology of the Bataks and Sukasman's innovative way of thinking about the wayang. For Eko Nugroho and Wayang Bocor, created by him in 2008 , the inspiration from the very beginning were the themes, motives, content and forms present in his earlier works. Born in 1977, a representative of the young generation of Indonesian artists who entered the art scene at the turn of the 20th and 21st century, used the critical potential of wayang in his works right from the beginning. His art, which includes both comics and street art, as well as sculptures, tapestries, installations, films and performances, can be - like Heri Dono's work - referred to as glocal art. It combines traditional Indonesian art, such as batik or wayang, with global popular culture, exposing the absurdities of Indonesian political life and making a critical diagnosis of the problems affecting Indonesian society. "In Indonesia the political situation is getting better, but there's still a lot of narrow-mindedness and social pressure, and that's exactly what I'm critical of in my work.")

An equally important topic addressed by Nugroho is the issue of the complicated negotiations of Indonesian identity. Attempts to define it have been ongoing since the beginning of the 20th century, the period called the Indonesian National Awakening (Kebangkitan Nasional Indonesia), when awareness of being one nation began to shape among the inhabitants of the erstwhile Dutch East Indies. More than 70 years after proclaiming independence, the Indonesian identity still seems to elude a precise description. Perhaps this is why the faces of many heroes of Eko Nugroho's work are covered with masks, stones, TV sets or other objects, depriving characters of identity. Eko Nugroho moved his heroes into the world of wayang, creating, in 2008, Wayang Bocor. Bocor means "cracked" or "leaky" in Indonesian. This term forewarns viewers of possible imperfections and deviations from tradition in the visual and theatrical experiment conducted by Nugroho. Cracks, blem-

6) Eko Nugroho (bio). 
ishes, and everything that diverges from the norm, have fascinated people for centuries. The fascination with otherness and exoticism is one of the most frequently discussed issues in contemporary postcolonial studies explaining the mechanisms of colonialism and orientalism. Contemporary artists who question the existing post-colonial order create works from contradictions, often located on the border between cultures and arts, exploring everything that has not yet deserved attention.

Eko Nugroho, transferring his characters to the world of wayang, created a theatre situated at the intersection of the world of art and performance, theatre, dance and music. Designing his puppets he used the motives, contents and forms present in his earlier works: "Peculiar figures, such as stone-headed man, diamond-hearted man, and pincer-handed man, are common in his paintings, drawings, and embroideries. Combining fantasies and daily life is his way to represent a world view about ambiguity and contradiction. In wayang purwo, classical wayang depicting stories derived from the epics Mahabharata and Ramayana, contradiction is constantly underlined. The difference is, whereas the figures in classical wayang have fixed characteristics, Eko Nugroho's wayang figures were designed to be free of any specific characteristics. This flexibility was intended to make these puppets available to be used by any one with any story."

The puppets designed by Eko Nugroho were made of leather or plexiglass and measured between 90 and 100 centimetres. The artist replaced the traditional cut of the leather ornaments with his own technique resembling inlay. "The wayangs were only painted on only one side to maintain the transparency in order to enhance the colors of the shadows. Even though these are not new ideas, in the end, these wayangs created by Eko Nugroho represent a unique form and fresh visualization." ${ }^{\text {) }}$

With each successive performance, Wayang Bocor evolved the technique of animating puppets. Initially dalang Ki Catur Benyek Kuncoro, while working with Wayang Bocor, tried to animate the puppets in a relatively "traditional" way, sitting behind the screen so the audience could only see shadows. In the performance Bungkusan Hati di dalam Kulkas from 2008 three screens were used, different in shape and size, which were filled not only with characters but also with elements of scenography. Both the performance and the space in which it was shown were inspired by the black and white animations of

\footnotetext{
7) Swastika (2009).

8) Swastika (2009).
} 
Eko Nugroho and his comics published since the late nineties. That is why light and light effects created through screen projections designed Ignatius "Clink" Sugiarto - associated with Teater Garasi from Yogyakarta - became important elements. The audience witnessed the game of contrasts played out between "the object and the shadow, the light and the dark, the real and the unreal, the hidden and the exposed." In the next performance, in 2009 in Yogyakarta, in Rumah Seni Cemeti Gallery, on the occasion of the vernissage of Eko Nugroho, Berlian Ajaib (The Wonder of Diamond) was shown. The same set of puppets was animated by three puppeteers standing behind the screens. Thanks to the handles that allowed the puppets to keep some distance from the screen, it became possible to "juggle" with puppets among screens or to perform other stunts. The puppets, although "hidden" behind screens, in certain moments were visible, like puppeteers who came out from behind the screens during the prologue, forming a second performance plan.

In 2014, after a few years break, Wayang Bocor returned in a new, refreshed form. Eko Nugroho decided to invite new artists who represented various fields of art to collaborate and this moved Wayang Bocor into a more intermedial and interdisciplinary art. This time, the main focus was put not on puppets animated by dalang, but on developing the technique just marked in the Berlian Ajaib performance, a combination of puppets and actors. The shadows were created not only as a result of puppet animation at one of the three screens (this time single, rectangular screen was placed in the middle of the scene and two tall, oval screens on either side), but also as a result of the use of the actors' acting and shadows built with their own bodies. So the actor became the shadow puppet, and his body - like the bodies of puppets designed by Eko Nugroho - was deformed by the costume. In a Hikayat AgarAgar Bertanduk performance from 2014, the main character Ali (Muhammad Nur Qomaruddin), wore a structure that is located mostly on the tops of the Indonesian mosques (Kubah Masjid) which deformed his head while his coactress Seroja (Theresia Wulandari) wore a colourful costume combined with a flower mask that covered her face, modelled on one of the sculptures of Eko Nugroho. Covering the faces of the main characters made them similar to the puppets designed by the artist, also depriving them of particular personality traits, ready to "create" in every subsequent performance again (fig. 2).

The story of the main characters, Ali and Seroja, was commented on by Punakawan. In a traditional wayang, they play a special role. In each per-

9) Swastika (2009). 
formance there is a scene called the gara-gara (or goro-goro), in which the dalang can comment on what has happened on the screen, laugh at some of the characters, teach the viewers or fill time with more or less censored jokes. This scene is one of the few moments during the performance, in which the puppeteer does not follow the strict rules. Just the opposite. He is expected to improvise, and the quality and style of his improvisation are the best indicators of his talent as a puppeteer.

In the traditional wayang, Semar and his three sons Bagong, Petruk and Gareng are called Punakawan. In the Wayang Bocor performance, only the last three appeared. Bagong, Petruk and Gareng although resembling traditional puppets, like other Nugroho characters, had deformed bodies. Their heads were placed in colourful bubbles (fig. 3). More importantly, the puppets only had the upper parts of their bodies, which forced the creation of a new technique of animation. The way in which each of the Punakawan moves is one of the most important features describing their nature; therefore, depriving them of legs and making them the same in height requires other indicators in order to read personality traits. An equally big challenge for puppeteers working with Eko Nugroho was how to animate puppets invented by the artist, previously unknown in wayang. Not only were the handles used by him difficult for dalangs. Often, as in the case of the Berlian Ajaib performance, thinking about the space created by the dalang during the performance required some revision. The puppets, created by Nugroho, with their sharp edges and changed conventional proportions, with handles in the middle and not at the end of the arms, were also much larger and heavier. So the dalang could animate only one puppet at a time, rather than two or more simultaneously. That's why not only the design of puppets was innovated by Wayang Bocor but also the animation technique. The conception of space and way of thinking about the dalang's body can be considered innovative too (fig. 4).

Both for Heri Dono and Eko Nugroho, wayang was a source of inspiration and experiments from almost beginning of their artistic creativity. The last of the artists described in this paper has gone the other way. Samuel Indratma, born in 1970, from the very beginning of his artistic career tried to move art out of the galleries and museums to present it to the wong cilik, people who previously had no contact with contemporary art. Murals designed and painted by him began to appear in various places of Yogyakarta in the late nineties. They were not only intended as a way to decorate the streets or 
buildings but also to communicate important messages for local communities to help develop local identity.

The wayang created by Samuel Indratma in 2014, written out for two intertwining projects - Wayang Rokenrol and Wayang Papet - draws the least (of all the new wayangs presented in this paper) from the artist's work in the field of visual art. Samuel and the artists collaborating with him are gathered in a group called Folk Mataraman Institute. Indratma is not only the originator, but also the artistic director, designer of puppets and dalang. He collaborates with musician and composer Sri Krishna and music director Bagus Mazasupa. Many others join them - Ampun Sutrisno, a choreographer who often appears as an actor, Loko Nusa the scenographer and lighting director, as well as three other prominent visual artists: Nasirun, Putu Sutawijaya and Djoko Pekik, who act as consultants. In each performance they emphasize that they are somehow intruders in the word of wayang, that they are artists who share a fascination for shadow theatre. Tradition is their starting point for formal experiments, which lie on the border of theatre, happening and installation. The puppets designed by Samuel Indratma are not a simple transfer of characters from his paintings and murals into the world of wayang. The artist pays great importance to the traditional way of making puppets, designing each of them in collaboration with experienced producers of wayang kulit. But the traditional way of making puppets does not mean a traditional way of animating them. On the contrary. They require new technique. Samuel, in the most intentional way among other artists, tries to explore the movement of puppets on the screen, looking for solutions from other known puppetry techniques from different parts of the world. He designed puppets for his first performances following the model of Turkish shadow puppets, from karagöz theatre (fig. 5). They only had one handle, fixed perpendicularly to the puppet, for the dalang to animate them and similar handles to move the hands. The puppets were animated not by Samuel, but by an actor who was visible on the screen and who played also as a shadow built by his own body. During the performances, Samuel, like Sukasman, embodied the role of "over-dalang", narrating in front of the screen.

His designs [projects], with simplified English terms, were also an ironic comment on the assimilation of western pop culture by Indonesians. It has been replacing Indonesian tradition, in music and theatre. One of the most important subjects undertaken by Heri Dono, Eko Nugroho and Samuel Indratma is the presence of tradition in the life of Indonesians today. They use the critical potential of wayang, referring to traditional and non-traditional 
ways of using puppets and in this way create a new language of artistic expression often directed towards a new audience, looking for the latest aesthetic and artistic challenges. What, then, is the significance of wayang in the field of contemporary art? The wayang created by them, although not the main area of their artistic activity, seems an important example showing the development of wayang kontemporer in recent decades. The presence of Heri Dono, Eko Nugroho or Samuel Indratma, visual artists educated at the faculty of fine arts in Institut Seni Indonesia in Yogyakarta, can be understood by many in the world of wayang, as an attempt to "museumify" wayang. Wayang puppets, deprived of performance context, are sold on the Internet, shown in contemporary art galleries, ethnographical museums, form part of the collections of the greatest museums in the world. They become objects of visual and ethnographic research, thereby departing the world of performance, and often becoming an exotic symbol of Indonesia. Heri Dono in his non-wayang works often criticizes the way in which traditional Indonesian culture is presented and perceived in the West. In his installation Museum Ethnography (Ethnographical Museum) from 2001, in nine metal tins in which snacks (krupuk, kerupuk) are most often kept in Indonesia, Dono enclosed objects that usually represent Indonesia at exhibitions in Ethnographical Museums worldwide. Beside miniature wayang puppets, there were also fragments of old maps and photographs symbolizing the "Other", an exotic world frozen in time, presented as seen by colonizers. A work with a similar overtone was presented at the Singapore Biennale in 2013 by Nasirun, cooperating with Samuel Indratma. In the installation Between Worlds, he used tens of miniature shadow puppets designed by him which were placed in glass bottles similar to dead scientific preparations used in labs.

In the case of the theatrical creativity of Heri Dono, Eko Nugroho and Samuel Indratma, the process, however, is opposite. Works of art created by them previously have entered the world of wayang, becoming an inspiration for their puppets and characters, written scenarios, imagined and designed new space in which they show their works. 


\section{BIBLIOGRAPHY}

Cohen 2019 = Cohen, Matthew Isaac, "Wayang in Jaman Now: Reflexive Traditionalization and Local, National and Global Networks of Javanese Shadow Puppet Theatre", Theatre Research International, March 2019.

Eko Nugroho (bio) = https://www.artsy.net/artist/eko-nugroho, accessed 19 August 2016.

Mrázek 2005 = Mrázek, Jan, Phenomenology of a Puppet Theatre, KITLV Press: Leiden 2005.

Rath 2003 = Rath, Amanda, "Shadow Stories: Wayang in the Work of Heri Dono", Prince Claus Fund Journal, no 10a, 2003.

Swastika 2009 = Swastika, Alia,

http://ekonugroho.or.id/index.php?page=artwork\&cat=Shadow\%20Puppet $\% 20$ Project, accessed 19 August 2016.

Welling 2009 = Welling, Wouter, The Dono Code. Installations, Sculptures, Paintings, KIT Publishers: Amsterdam 2009.

Zeplin 2007 = Zeplin, Pamela, "Winged horse dreaming: Heri Dono in Adelaide", Dream Republic, exhibition catalogue, Adelaide 2007. 

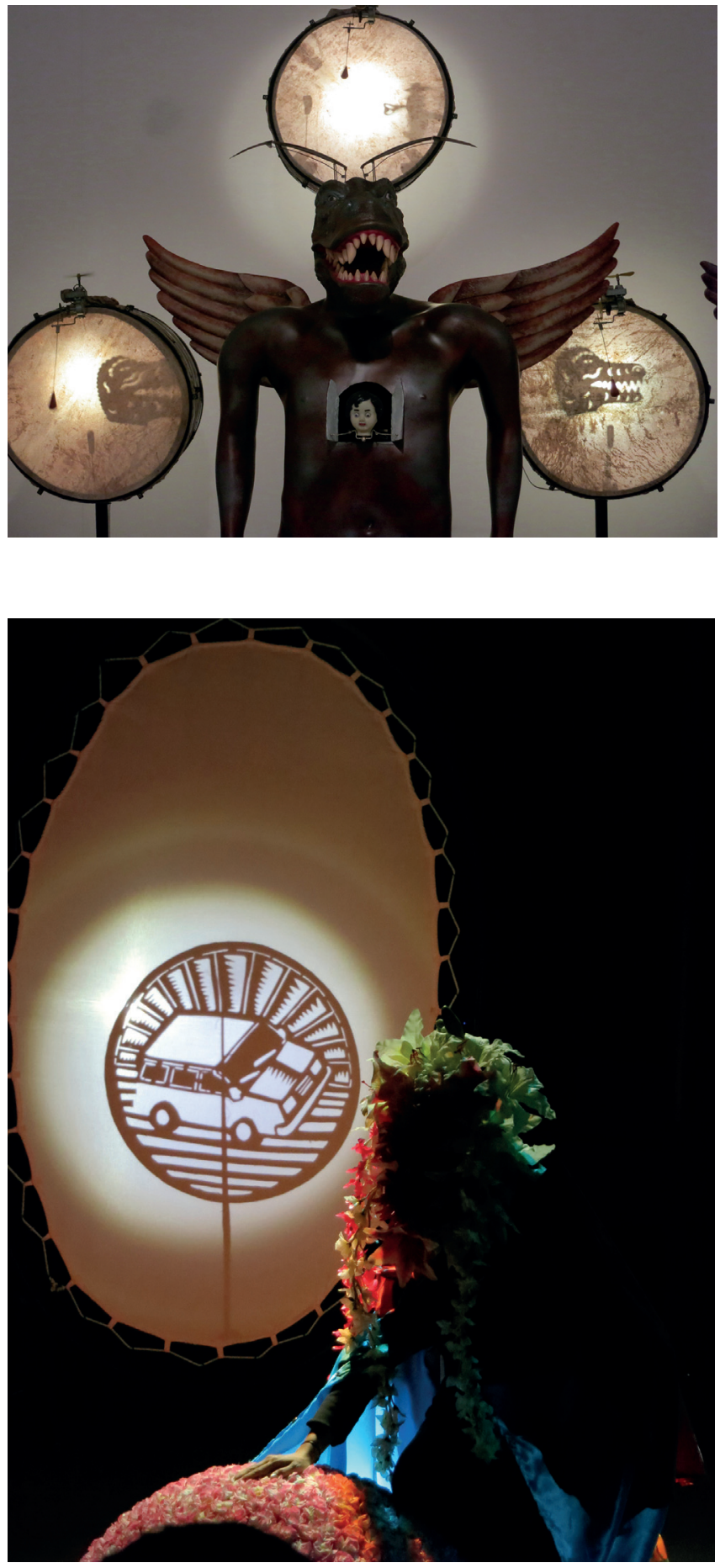

1. Heri Dono. The Three Donoraurus. Installation. 2013. Photo M. Lis.

2. Wayang Bocor, Hikayat Agar-Agar Bertanduk, Yogyakarta, 11.07.2014. Photo M. Lis. 


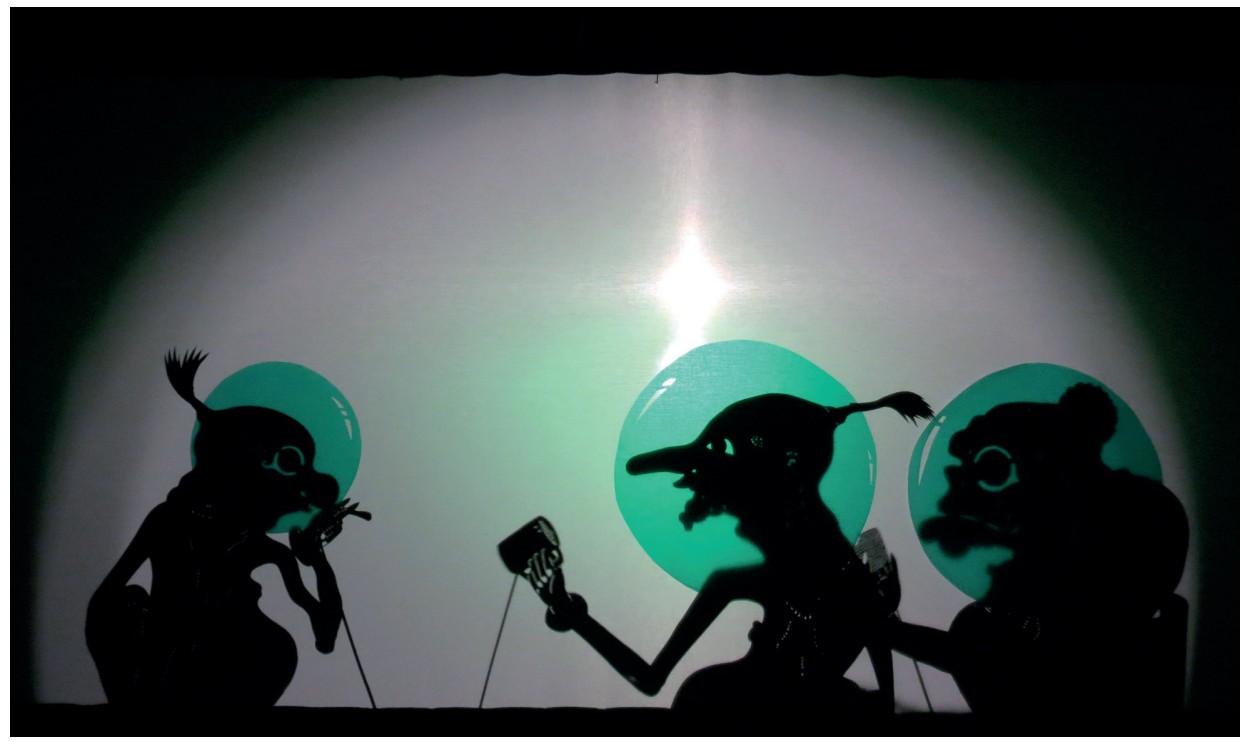

3. Wayang Bocor, Hikayat Agar-Agar Bertanduk, Yogyakarta, 11.07.2014. Photo M. Lis.

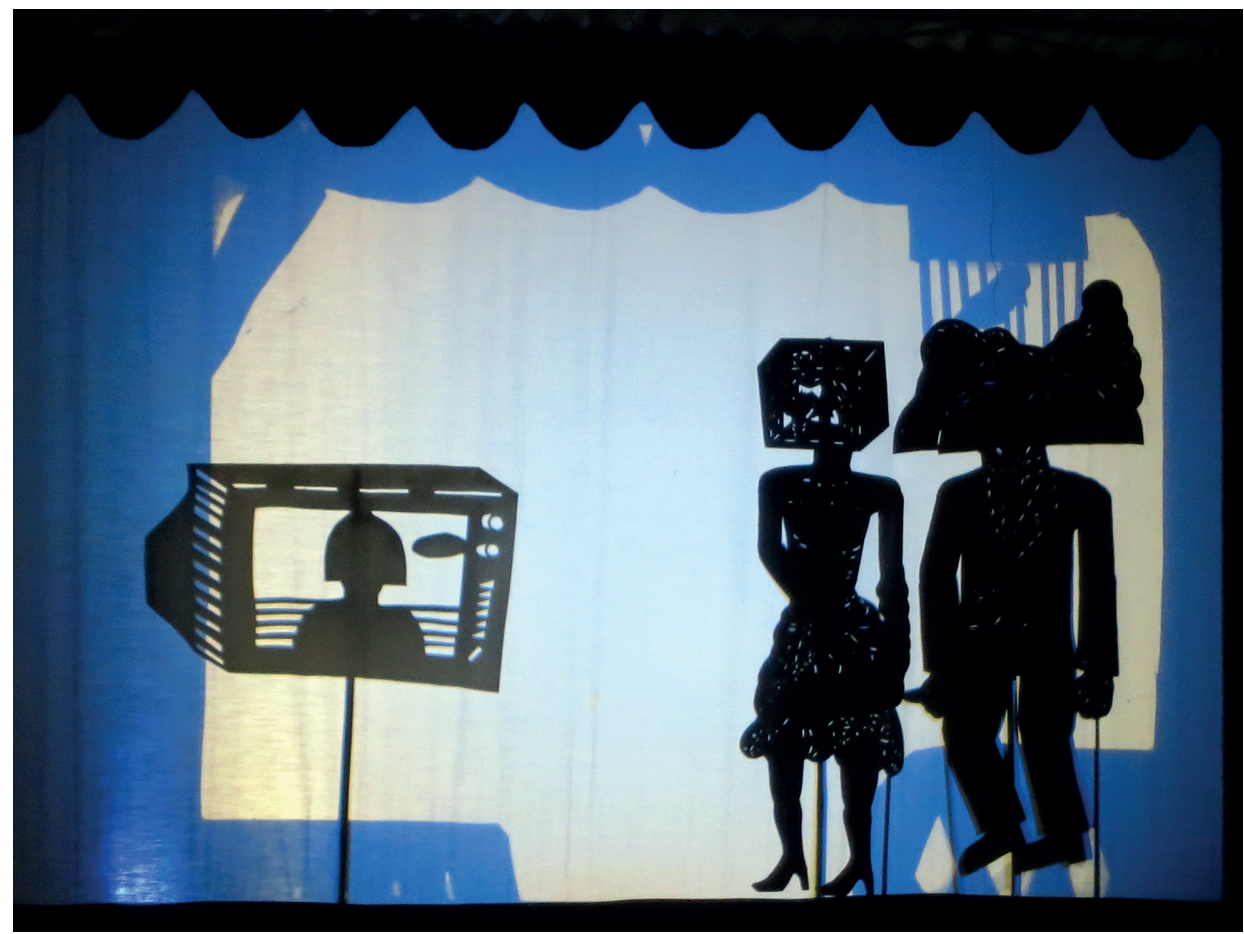

4. Wayang Bocor, DiMiscall Leluhur, Yogyakarta, 07.12.2014. Photo M. Lis. 


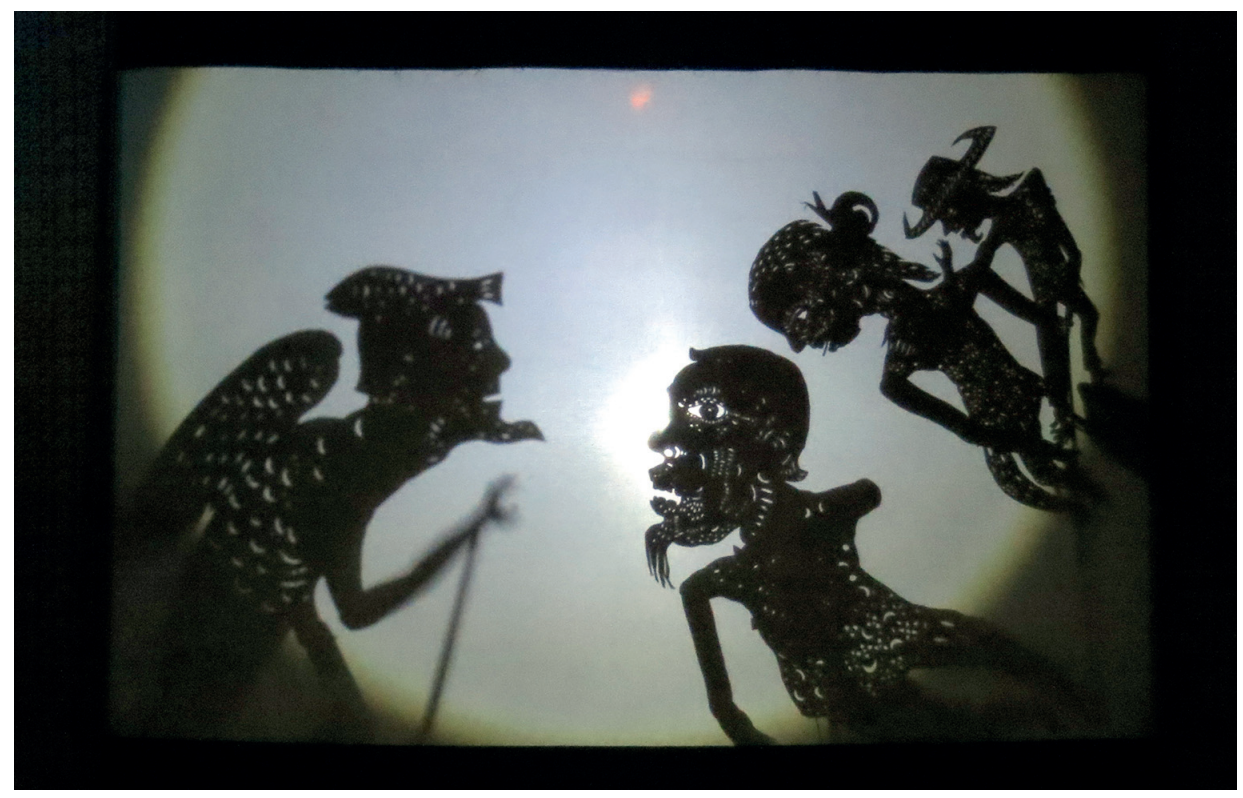

5. Wayang Papet, Yogyakarta, 31.07.2015. Photo M. Lis. 